ORIGINAL ARTICLE

\title{
The role of self-assessment and emotions in designation of an aggressive strategy of coping with a social conflict situation by gymnasium school students
}

\author{
Danuta Borecka-Biernat \\ Institute of Psychology, University of Wroclaw, Wroclaw, Poland
}

BACKGROUND, PARTICIPANTS AND PROCEDURE

This research is aimed at evaluation of the role of self-assessment and emotions in designation of an aggressive strategy of coping with a social conflict situation by gymnasium school students. It uses a questionnaire to study strategies adopted by youth to cope with a social conflict situation (KSMK), Self-Esteem Scale (SES) and a Three-Factor Personality States and Traits Inventory (TISCO) questionnaire. The empirical study was conducted in gymnasium schools in Wrocław and neighbouring localities. It included 811 adolescents (414 girls and 397 boys) aged 13-15.
RESULTS AND CONCLUSIONS

Based on the analysis of the collected research material, it is concluded that low assessment of teenagers' own capacity plays a role in choosing an aggressive strategy to cope with a social conflict situation. Participation of adolescents in a situation of a threat to accomplishment of their own objectives intensifies negative emotions. Research results confirm that aggression is a form of dealing with anger and fear felt in a social conflict situation.

\section{KEY WORDS}

gymnasium school students; self-assessment; emotional reactions; aggressive strategy of coping; social conflict situation

CORRESPONDING AUTHOR - Danuta Borecka-Biernat, Institute of Psychology, University of Wroclaw, Poland, e-mail: d.borecka-biernat@psychologia.uni.wroc.pl

Authors' contribution - A: Study design · B: Data collection · C: Statistical analysis · D: Data interpretation · E: Manuscript preparation · F: Literature search · G: Funds collection

TO CITE THIS ARTICLE - Borecka-Biernat, D. (2014). The role of self-assessment and emotions in designation of an aggressive strategy of coping with a social conflict situation by gymnasium school students. Current Issues in Personality Psychology, 2(1), 17-29. 
The role of self-assessment and emotions in designation of an aggressive strategy of coping with a social conflict situation by gymnasium school students

\section{BACKGROUND}

Difficult situations are not something exceptional in the human life. They do not constitute a uniform class of situations, but a clearly internally-diversified group. In particular, difficult social situations should be considered. As M. Tyszkowa claims (1979, p. 211), "values and objectives of an individual are subject to threat or frustration by other people through the very fact of their presence, or as a result of specific forms of their impact, that is opposing or just inconsistent with one's own endeavours (objectives)". Among situations of this type, M. Tyszkowa (1979) distinguishes social conflict situations, in which one's own endeavours are contrary to or inconsistent with other people's endeavours and their fulfilment is threatened.

In the teenagers' life there occur particularly frequent difficult situations of social interactions which include an element of hazard to fulfilment of endeavours or accomplishment of objectives (satisfaction of needs). Research results obtained above all by Guszkowska, Gorący \& Rychta-Siedlecka (2001), Różańska-Kowal (2004), Woźniak-Krakowian \& Wieczorek (2009) and Miłkowska (2012) have proven that adolescents usually regard school as a source of the biggest threat. Difficult social events in school environment include oral tests by teachers, graded tests, exams and other situations verifying knowledge, criticism and disapproval by a teacher, as well as public presentation and becoming the laughing stock of peers. Domineering pressure and inflexibility of teachers' requirements are also related to school. Students are expected to assimilate and reproduce knowledge from each area, without consideration of their individual features, interests and abilities. This causes conflict situations in the student-teacher relationship.

Research by Miłkowska-Olejniczak (2002) has indicated that school environment is characterised by conflict situations among students during lessons, while more than one-third of the asked students emphasise situations of conflict with teachers. Plewicka (1977) has studied school conflict situations among students aged 14-19.68\% of school conflicts described have concerned those with teachers. School grades are the most controversial situations in the student-teacher relationship. Usually, students blame teachers for grade underestimation, non-appreciation of student's effort, not noticing any improvement, favouring selected persons or giving failing grades not for the performance, but for other deeds. Tactless behaviours of teachers constitute another group of conflict factors described by students. They are manifested in mockery, insults, ridicule, depreciation of features of one's own image, behaviour, character and general value of a student as a human being.
It is worth emphasising, as Plewicka (1977) notices, that conflicts between students and teachers are generally difficult for a student, yet insignificant for a teacher who often does not notice them or depreciates them. However, the longer the students stay at school, the more often the student-teacher conflicts occur. In turn, descriptions of peer conflicts constitute $32 \%$ of the material collected by the author. She divides them into individual, individual-group and informal-formal group conflicts. Elementary school has provided the most descriptions of individual conflicts (45\%). They are caused mainly by provocations and mockery, groundless suspicions, slander, treason, indiscretion, competition for grades, popularity among the opposite sex, or rude behaviour. Individual-group conflicts show a decreasing tendency as the time spent at school goes by. In the two last grades of the elementary school, they constitute $37 \%$ of the collected material. The most popular of them include conflicts against social isolation of a student from a group, social differences between a student and the majority of the group, as well as otherness of a student as compared to the group. As the research conducted by this author shows, a small number of students has been strongly identifying themselves with a group and described inter-group conflicts as their unpleasant school experience. It appears that conflicts among the girls' "gangs" are being established due to competition for boys' favours and school grades. In turn, antagonistic boys' "gangs" compete mainly for power over a class and sports prestige. In this author's opinion, despite their strong emotional charge, peer conflicts are short-term and their frequency is decreasing as students are staying at school. It does not mean that conflicts constitute a marginal phenomenon in students' social life. In addition, situations outside the school, i.e. conflicts with friends, partners - boyfriend or girlfriend, peer disrespect, constitute the source of tensions and difficult situations for young people. Różańska-Kowal (2004) notices that peer conflicts occur due to differences in views, as well as uncontrolled impulsiveness and outbreaks of anger for often insignificant reasons. Conflicts and breakups with boyfriends are difficult situations for girls.

Apart from everyday difficulties related to school, family problems constitute another source of unpleasant experience. They are connected with family relations (Pufal-Struzik, 1997; Krzyśko, 1999; Kobus \& Reyes, 2000; Różańska-Kowal, 2004). Lack of agreement, disturbed contacts with parents, limitations on satisfaction of some adolescents' needs, parents' rigorous control constitute an important source of tensions as young people are growing up. Many of these conflicts concern everyday situations - differences in opinions, tastes, e.g. in matters related to clothes, music, spending free time or hometime. Here we have to do with a conflict of the need for autonomy increas- 
ing at young people and parents' standards, charges, bans, tendencies to control, supervise adolescents and their behaviour. Parents desire their children to be perfect and accomplish the objectives they did not manage to accomplish. They impose a great burden of obligations and expectations on their children, which is an attempt of enforcing fulfilment of family duties. Adolescent-parent conflicts are a common phenomenon and they have been considered quite broadly in the research conducted by Jaworski (2000). This author demonstrates that non-consideration of the fact that adolescents are not identifying themselves with parents constitutes an important reason for deteriorating relations between children and parents. Adolescence is a stage of discovering new authorities, new demands and changes in the system of values. Therefore, separateness of the system of values preferred by the world of adults and adolescents affects establishment of a generation gap. Adults are getting more and more critical, so parents' authority is in crisis and conflicts with them are increasing. Pubescence includes increased interest in the opposite sex. Choice of a boyfriend/girlfriend by an adolescent may prompt parents' dissatisfaction and constitute a breeding ground for a conflict. An adolescent demands absolute tolerance and acceptance of the chosen person and total freedom in their "love life". Similarly, adolescents disapprove of their own image, overstate their imaginary flaws and beauty defects, therefore they have pretensions to their own silhouette and to their parents. Undoubtedly, changeable feeling, mood swing, impulsiveness, susceptibility triggered by teenagers' hormonal storm annoy parents as they are not able to control emotional processes of their children, which, in turn, becomes a breeding ground for conflicts. It is worth emphasising that, as Matusewicz (1997) notices, disagreements and conflicts with mother and father occur in approx. 55-65\% of the population of elementary and secondary school students, while boys are more conflicting than girls. The intensity of family conflicts is also very high.

Difficult situations cannot be excluded from the human life. Usually, adults do not realize how many difficult situations young people need to face. Everyday life of many adolescents carries various traumatising events, is full of stimulating phenomena with elements of challenge, competition, conflict and fight. Reports on somatic and psychical costs of a teenagers' life in situations constituting the source of stress are alarming (see Witkin, 2000). Undoubtedly, the way the youth deal with everyday events constitutes one of more important predicators protecting them against negative consequences of living in stressful conditions. Activities taken by a human being in a difficult situation are regarded in a specific situational context as a strategy of coping with a current difficult situation (see Wrześniewski, 1996).
It aims at resolution of a problematic situation and/ or alleviation of harsh emotional strain accompanying a difficult situation (see Kosińska-Dec \& Jelonkiewicz, 1995). Numerous researches and even common observation indicate that teenagers adopt various strategies of coping with difficult social situations (see Donaldson, 2000; Frączek, 2003; Różańska-Kowal, 2004; Sikora \& Pisula, 2008). They include an aggressive strategy, which takes the form of an initiated physical or verbal attack on specific persons, causing physical, psychic and social damage to other people's welfare (i.e. causing pain, suffering, destruction, leading to a loss of appreciated values). It occurs when an individual assesses an experienced situation as the one causing hazard to his welfare (see Stach, 1989). The strategy of aggressive response to difficulties is not oriented towards solving and overcoming a difficult situation. It allows only for reduction of harsh emotional strain. An initial aim is replaced with another one - comfort. An individual adopting an aggressive strategy does not burden himself with difficulties of solving a problem. In a longer term, an unsolved problem causes a sense of dissatisfaction with achievements of other persons, as well as a sense of helplessness and lack of control over a difficult situation (see Borecka-Biernat, 2006).

As far as we know, human coping strategies are analysed always in a specific difficult situation as they depend largely on their perception. Then, it is worth noticing the way the youth handle conflict situations at school, in peer relations or at home. Previous research results have indicated that school environment is particularly stressful for adolescents - this concerns especially conflicts with teachers and schoolmates. Moreover, empirical material in the literature indicates that teenagers apply many strategies of coping with school problems (see Różańska-Kowal, 2004; Polak, 2010). Among such strategies, teenagers mention aggressive behaviour against persons and objects. Data obtained by Nitendel-Bujakowa (2001), Woźniak-Krakowian \& Wieczorek (2009), Miłkowska (2012) show that subject classes constitute situations particularly favourable for aggressive ways of stress release. Students asked about reasons for aggression during classes mention above all fear of low grade, fear of failure, a lot of homework, unannounced tests, teacher's dislike of a student, fear of reprimand, fear of malicious comments, fear of impaired opinion and peer relations. Student aggression consists above all in intentional hampering of class conducting by teachers, destroying personal objects left on a teacher's desk, expressing bad opinions on a teacher towards peers and parents. In addition, it is worth adding that more than a half of the asked students admit that they behave aggressively during breaks between classes. Here, symptoms of physical aggression (buffeting, pushing, kicking) prevail, while verbal aggression is manifested in naming, mocking a per- 
The role of self-assessment and emotions in designation of an aggressive strategy of coping with a social conflict situation by gymnasium school students

son or his stuff, taunts. Sequestered rooms (locker room, hallway, toilet) where students stay most often without teacher's presence, constitute a particular risk during breaks between classes. Students asked about reasons for aggression during breaks indicate mainly getting even with somebody and conflicts. A significant number of students have conflicts with other students and hence experience harsh emotional strain. Students release this strain usually by arguing, naming, mocking or fighting.

Frączek (2003) has conducted an interesting research on strategies of coping with conflict situations in a peer group. 9-, 11- and 15-year-old girls living in Israel, Finland, Poland and Italy have taken part in it. Results of this research demonstrate that girls handle conflicts better than boys and they strive for agreement more often. The aggressive strategy is more common among boys than girls. Aggression of boys and girls has different forms. In the case of the latter, it is more indirect, hidden, used for defence. It is passive, has a form of telling on, accusing, pouting and emotional rejection. Boys use open, physical, more active and direct forms of aggressive behaviour. This research shows that younger children use more often physical and instrumental aggression, while older ones - verbal and hostile aggression.

As children are growing up, conflict situations with their parents become a more and more important source of tensions. As Jaworski (2000) notices, conflicts in the child-parent relationships are a common phenomenon in the adolescence. Children at an older school age want to break their parents' wardship and demand rights broader than ever before with all their behaviour. Obstacles and failures they come across as well as bans and limitations posed by their parents trigger angry reactions. They are expressed by arrogant answers, door slamming, sometimes cry or direct acts of aggression oriented towards objects or persons. Aggression of adolescents against their parents is manifested in words, ironic statements, ignorance of their commands or silence. The author concludes that teenagers in conflict situations often show much ruthlessness, aggression, brutality, indifference, and even cynicism.

Previous considerations prove that a social conflict situation is associated with problems of aggressive strategy of coping with a specific situational context, aiming at avoidance or minimisation of losses, unfavourable effects. One should ask why teenagers in a social conflict situation choose a strategy of aggressive response to difficulties. In the opinion of Tyszkowa (1986), basic cognitive structures of a personality, which indicate processes of perceiving an external situation and emotional reflection by an individual of the significance of this situation and the course of one's own actions, play an important role in psychological mechanisms of human behaviour in difficult situations.
Information concerning an individual, features composing the knowledge about oneself constitute a premise to evaluation of one's own capacity in difficult situations (see Tyszkowa, 1986). As far as we know, self-assessment constitutes an evaluative component of the "self" structure (see Kozielecki, 1981). The impact of the self-assessment is manifested by the way an individual functions in difficult situations. The way an individual proceeds, behaves in various, especially difficult, situations, the way their relations with other people are working out, is closely related to the way they evaluate themselves. It appears that in difficult situations, an unfavourable, insufficiently organised and misguided structure of self-image is threatened, which causes - according to Tyszkowa (1977) - intense negative emotions and move of the activity purpose towards a defence of one's "self". Instead of focusing on a problem, an individual directs their actions to defend their own image. This results in disorganisation of a purpose-oriented action and a behaviour that constitutes an attempt of coping with a threat to one's "self". Inadequate self-assessment plays an unfavourable role in human behaviour in difficult situations. It reduces psychic immunity to difficult situations, causes negative emotions and decreases the effectiveness of operations or coping with a difficult situation (see Reykowski, 1970; Tyszkowa, 1979). Therefore, when an individual faces a difficult situation, too low or too high self-assessment leads to an increased sense of personal threat, negative emotions and intense disorganisation of behaviour. Inadequate self-assessment, as Reykowski (1970, p. 52) emphasises, "is related to violation of a regulative function of personality, thereupon an individual is not able to cope well with difficult situations". Persons manifesting an adequate and high level of self-assessment are the least susceptible to disorganisation of their behaviour in a difficult situation (see Bishop, 2000; Ogińska-Bulik, 2001). Research results obtained mainly by Tyszkowa (1997), Kubacka-Jasiecka (1995), Rostowska (2001), Ogińska-Bulik (2001), Borecka-Biernat (2006), Eftimie \& Ionescu (2010) show that a tendency of aggressive behaviour occurs in the event of too low and too high (inadequate) assessment of oneself, their capacity and operational efficiency in the face of various difficult events. It is worth mentioning here the empirical data from Kulas (1986) research which indicate that contacts of twothirds of adolescent girls and boys with low self-assessment with peers in a school class have been disadvantageous and conflicting, while only $6.7 \%$ of persons of high self-assessment have defined their peer relations in that way. Moreover, Kulas (1986) research shows that extremely high self-assessment is not beneficial to good relations with others. Usually, students with such self-assessment are characterised by conceit, undue self-confidence, disrespectful approach towards the others and inconsideration of 
the public opinion. They blame teachers, sometimes parents or friends for lack of successes in learning - never themselves. Blaming others is accompanied by aggression, thereupon it violates proper relations with others. Therefore, too high, inadequate self-assessment causes that an individual follows rather his desires than actual capacity in his proceedings. This conditions an uncritical readiness to take actions, when one's capacity does not justify their performance. An individual does not accomplish what they expected, hence expose themselves to frustration and disappoint others due to improper performance or non-performance of a task. They are often accused of lack of responsibility, exposed to disapproval and reprimand. When they defend themselves against these harsh consequences, they try to reduce their own faults by trying to shift the responsibility onto others, thereupon causing a conflict with the environment.

Previous research concerning a correlation between self-assessment and aggression has enabled us to state that too low and too high (inadequate) self-assessment is accompanied by aggression manifested by an individual in a social conflict situation. Therefore, too low and too high (inadequate) self-assessment reduces psychic immunity to difficult situations, effectiveness of one's own operations and hampers an individual's adjustment or management in a difficult situation. Even a small obstacle or threat may cause an outrageous aggression of persons with too low and too high (inadequate) self-assessment.

A human being responds emotionally to a difficult situation. Emotional reactions in such a situation are related to an individual's personality features, as well as the way they perceive this event (see Łosiak, 1995). In a difficult situation emotions are intensive and usually negative. Persistent emotional excitation of high intensity and negative character constitute the basis for aggressive behaviour, irritation, anger outbursts and other seemingly unjustified emotional reactions that may be observed in various types of destructive behaviour (see Terelak, 2001). Emotions in line with the sequence: irritation - exasperation - anger lead to aggressive behaviour. Their intensity defines intensification and form of aggression. As Łosiak (2009) notices, exasperation and anger constitute related emotional states similar at the level of subjective experience and a link to aggressive behaviour. The experience of anger involves specific somatic sensations, e.g. simmering, fuming or relations of experiencing strong tendencies to aggressive behaviour, e.g. to hurt somebody or destroy something. It should be noticed that anger and exasperation are one of possible negative emotional responses during a stressful situation perceived as a threat or loss/harm (see Lazarus, 2001). According to Berkowitz (1992), anger and exasperation trigger actions aimed at recovery of threatened or lost aims of activity and they lead to aggressive behaviours. In addition, Skorny (1987, p. 97) veers towards this opinion when he says "occurrence of anger and exasperation, willingness of harming, teasing, damaging or hurting constitutes a subjective equivalent of aggression”. Różańska-Kowal (2004) claims, as a result of the research she has conducted, that the capacity of reacting with exasperation is related to fighting, not giving up in difficult situations.

It seems that in natural conditions anger is an emotion that facilitates the action of fighting, while fear facilitates the action of running away. However, observations indicate that fear may be the reason for attack when an individual has nowhere to run away, when they have no other options except aggression or attack. It is commonly known that fear constitutes the basis for aggressive behaviour. It is one of important determinants of aggressive behaviour. Concurrence of the fear - aggression relation is indicated by Ranschburg (1993, p. 137) who compares fear and aggression to a reversible coat: "aggression and timidity are two sides of the same phenomenon [...]. It is similar to a reversible coat: if a timid side is out, aggression is directed inwards, but when aggression is out, timidity may be found inside for sure". It is also worth referring to Kępiński’s (1992, p. 292) statement: "in aggression a human being leaves an anxiety position of being hounded, where their space-time continuum is maximally shrunk and they hit the surrounding world with anger and despair. Destruction of some part of this world brings them relief and the sense of being a winner, that not only failure is their destiny". It is noticeable that aggression constitutes an aggressive form of coping with fear felt in difficult social situations. This reaction helps to release anxiety tension or hide fear. However, it is worth noticing that impact of fear on a behaviour depends on its intensity. Studies of Leary \& Kowalski (2001), Clark \& Watson (2002), Jelonkiewicz \& Kosińska-Dec (2008) show that fear of high intensity renders efficient overcoming of difficulties impossible, hampers spontaneous activity, reduces motivation to transgressive deeds, causes the loss of control over one's own behaviour, aggressive behaviour model, withdrawing or running away from a difficult situation. However, low and moderate fear enables one to make an effort to solve a problem through reorganisation oriented towards the purpose of activities. In general, fear of low intensity may stimulate an individual's behaviour, but its high intensity disorganises it, as it favours perceiving many situations as threatening, even if objectively they are nothing like this.

To sum up the above considerations, it may be stated that an aggressive strategy applied in a social conflict situation depends majorly on subjective variables formed in the course of various individual experiences, starting from early childhood. 
The role of self-assessment and emotions in designation of an aggressive strategy of coping with a social conflict situation by gymnasium school students

\section{AIM OF THE STUDY}

My own research is aimed at evaluation of the role of self-assessment and emotions in designation of an aggressive strategy of coping with a social conflict situation by youth. This research considers the sex of respondents.

It is aimed at answering the following research questions:

1. Is there any correlation between the self-assessment level and the youth's strategy of coping with a social conflict situation?

2. Is there any correlation between the level and content of emotions and the youth's strategy of coping with a social conflict situation?

\section{PARTICIPANTS AND PROCEDURE}

\section{PARTICIPANTS}

The respondent group has included 414 girls and 397 boys aged 13-15. In general, 811 persons - students of the first, second and third grades of gymnasium schools from Wrocław and neighbouring localities - have participated in this group research conducted in schools.

\section{PROCEDURE}

This research applies the Self-Esteem Scale (SES) by M. Rosenberg (Łaguna, Lachowicz-Tabaczek \& Dzwonkowska, 2007) and the Three-Factor Personality States and Traits Inventory (TISCO) questionnaire by C. Spielberger and K. Wrześniewski (see Wrześniewski, 1991), as well as the author's questionnaire to study the youth's strategies of coping with a social conflict situation (KSMK) (Boracka-Biernat, 2012).

Self-Esteem Scale (SES) by M. Rosenberg enables one to calculate the level of general (global) selfassessment of both teenagers and adults. SES includes ten diagnostic descriptive statements using which a respondent describes their "self" assessment. The scale of respondents' answers includes four levels, from "strongly agree" to "strongly disagree". Respondents might obtain from 1 to 4 points for each answer. Final results range between 10 and 40 points. A high result in the scale means a high level of general (global) self-esteem. The Polish version of the SES method is a reliable tool of verified theoretical accuracy.

Three-Factor Personality States and Traits Inventory TISCO constitutes a Polish version of American State-Trait Personality Inventory (STPI) test developed by a team of C. Spielberger (see Wrześniewski, 1991). TISCO contains two independent parts. The first part (SPI) measures fear, anger and curiosity treated as emotional states felt at a given moment. The second part (TPI) is applied to examine the same emotions treated as personality traits. Therefore, this test includes six subscales: fear as a state and fear as a trait, anger as a state and anger as a trait, curiosity as a state and curiosity as a trait. Each subscale includes ten short simple statements referring to subjective feelings of an individual. Results concerning reliability and accuracy of TISCO are satisfying and close to the original STPI version.

The author's questionnaire KSMK(see Borecka-Biernat, 2012) is dedicated to examine a strategy of coping with a social conflict situation adopted by adolescents. It includes descriptions of 33 difficult social conflict situations. Each situation has four behaviours assigned that express coping with a social conflict situation. The first one refers to aggressive coping (A), the second one to evasive coping (U), the third one to submissive coping (UI), and the fourth one to activity-based coping with a social conflict (Z). Results are obtained separately for each scale through summing up marked behaviours in 33 situations in a given scale. Scales include 33 items, therefore respondents might obtain from 0 to 33 points in each of them. KSMK questionnaire is characterised by favourable psychometrical parameters. Scale reliability coefficients established by the Cronbach's $\alpha$ method come from $\alpha=0.73$ (for the scales " $\mathrm{Ag}$ gression", "Submission" and "Activity") to $\alpha=0.694$ (the scale "Evasion"). Scale validity has been verified in many ways. Above all, convergent validity has been confirmed with reference to results of A-R K. Ostrowska questionnaire, the Children Assertive Behaviour Scale - CABS by L. Michelson and R. Wood in adaptation by M. Oleś and the questionnaire concerning styles of resolving conflicts by adolescents by $\mathrm{T}$. Honess, and presently in adaptation by B. Lachowska. Standards in the sten scale have been developed based on studying a sample of 1,877 students, including 975 girls and 902 boys aged 13-15, from the first, second and third grades of gymnasium schools from all 16 Polish voivodships.

\section{RESULTS}

In order to verify possible correlations between the level of general self-assessment and an aggressive strategy of coping with a social conflict situation, the results in SES and KSMK questionnaires have been correlated. Table 1 presents Pearson's $r$ correlation coefficients for the whole group and for groups distinguished by sex.

Data presented in Table 1 show that the correlation between the level of general self-assessment and the strategy of aggression is very low and statistically insignificant for the whole group and to girls $(p<0.05)$. In turn, a statistically significant weak negative correlation between the level of general self-assessment and the scale of aggressive manage- 
Table 1

Coefficients of Pearson's $r$ correlation between the results of the SES questionnaire and the "A" scale of the KSMK questionnaire for the whole group $(n=811)$, for girls $(n=414)$ and for boys $(n=397)$

\begin{tabular}{|c|c|c|c|}
\hline \multirow{4}{*}{$\begin{array}{c}\text { SES } \\
\text { Questionnaire }\end{array}$} & \multicolumn{3}{|c|}{ "A" scale of the KSMK questionnaire } \\
\hline & Girls & Boys & Total \\
\hline & $r=0.06$ & $r=-0.16$ & $r=-0.04$ \\
\hline & $p<0.27$ & $p<0.001$ & $p<0.28$ \\
\hline
\end{tabular}

Note. A - aggressive coping with a social conflict situation.

Table 2

Level of general self-assessment in a group of adolescents of a high (WA), medium (SA) and low (NA) level of aggressive strategy of coping with a social conflict situation

\begin{tabular}{|c|c|c|c|c|c|c|c|}
\hline \multirow[t]{3}{*}{ Respondents } & \multirow[t]{3}{*}{ Group } & \multicolumn{6}{|c|}{ Level of general self-assessment } \\
\hline & & \multicolumn{2}{|c|}{ Low } & \multicolumn{2}{|c|}{ Medium } & \multicolumn{2}{|c|}{ High } \\
\hline & & $n$ & $\%$ & $n$ & $\%$ & $n$ & $\%$ \\
\hline \multirow[t]{3}{*}{ Total } & WA $(n=382)$ & 99 & 25.92 & 143 & 37.43 & 140 & 36.65 \\
\hline & SA $(n=283)$ & 65 & 22.97 & 119 & 42.05 & 99 & 34.98 \\
\hline & $\mathrm{NA}(n=146)$ & 22 & 15.07 & 49 & 33.56 & 75 & 51.37 \\
\hline \multicolumn{8}{|c|}{$\chi^{2}=14.86 ; d f=4 ; p<0.05 ; C=0.13$} \\
\hline \multirow[t]{3}{*}{ Girls } & WA $(n=181)$ & 48 & 26.52 & 43 & 23.76 & 90 & 49.72 \\
\hline & $\hat{\mathrm{S} A}(n=152)$ & 45 & 29.61 & 49 & 32.24 & 58 & 38.16 \\
\hline & $\mathrm{NA}(n=81)$ & 13 & 16.05 & 23 & 28.40 & 45 & 55.56 \\
\hline \multicolumn{8}{|c|}{$\chi^{2}=10.15 ; d f=4 ; p<0.04 ; C=0.16$} \\
\hline \multirow[t]{3}{*}{ Boys } & WA $(n=201)$ & 51 & 25.37 & 100 & 49.75 & 50 & 24.88 \\
\hline & $\hat{\mathrm{SA}}(n=131)$ & 20 & 15.27 & 70 & 53.44 & 41 & 31.30 \\
\hline & NA $(n+65)$ & 9 & 13.85 & 26 & 40.00 & 30 & 46.15 \\
\hline \multicolumn{8}{|c|}{$\chi^{2}=14.49 ; d f=4 ; p<0.006 ; C=0.19$} \\
\hline
\end{tabular}

ment for boys has been noticed $(r=-0.16)$. A simple relation may be noted - the lower the level of general self-assessment, the more often boys use strategies of aggression in a social conflict situation. It may be assumed that the value of aggressive way in which boys handle a conflict will increase as the level of general self-assessment reduces.

In the view of a more thorough analysis of the existing correlations between the level of general self-assessment and an aggressive strategy of handling a social conflict situation, three groups with a high, medium and low level of aggressive strategy of coping have been compared with regard to the level of general self-assessment. Table 2 shows a comparison of the level of general self-assessment in a group of adolescents of a high (WA), medium (ŚA) and low level of aggressive strategy of coping with a social conflict situation.

Distribution of the data in Table 2 demonstrates that a low and medium level of general self-assessment is more often present in the case of teenagers (considering the group as whole) characterised by a high $(25.92 \%, 37.43 \%)$ and medium $(22.97 \%, 42.05 \%)$ level of aggressive strategy applied in a social conflict situation. However, a high level of general self-assessment is more frequent in a group of teenagers characterised by a low level of aggressive strategy of coping with a social conflict situation (51.37\%). Correlations outlined at comprehensive consideration of groups with a high, medium and low level of aggressive strategy of coping with a social conflict situation have been present also after taking the sex of respondents into account. Frequency of occurrence of a low and medium level of general self-assessment among girls and boys is higher in a group of teenagers characterised by a high (G: $26.52 \%, 23.76 \%$; B: $25.37 \%, 49.75 \%$ ) and medium (G: $29.61 \%, 32.24 \%$; B: $15.27 \%, 53.44 \%)$ level of aggressive strategy of coping with a social conflict situation. In turn, a group with a low level of aggressive strategy of coping with a social conflict situation (G: 55.56\%, B: 46.15\%) includes more girls and boys of a high level of self-assessment. 
The role of self-assessment and emotions in designation of an aggressive strategy of coping with a social conflict situation by gymnasium school students

When treating respondents as a whole, and with regard to girls and boys, distributions of results have been verified by their relevance. When a test $\chi^{2}$ is applied for a contingency board, the obtained value of statistics comes to 14.86 for the whole respondent population, 10.15 for girls and 14.49 for boys. It is higher than the critical value of 9.48 for the significance level of $p<0.05$ at four degrees of freedom.

The data in Table 2 show that there is a statistically significant relation between the level of self-assessment and the level of aggressive strategy of youth's coping with a social conflict situation (considering the group as a whole and distinguished by sex). The question arises about the strength of correlation between the self-assessment level and the youth's aggressive strategy of coping with a social conflict situation. To verify this, the method of mean square contingency $\mathrm{C}$, which is an indicator of a qualitative feature correlation (see Guilford, 1970), has been applied. Mean square contingency $\mathrm{C}$ coefficient obtained from $\chi^{2}$ comes to 0.13 for the whole respondent population, 0.16 for girls and 0.19 for boys. $\chi^{2}$ from which $\mathrm{C}$ is obtained is significance at the level of 0.05 , C differs significantly from zero correlation. It means that there is a statistically significant but low correlation between the level of self-assessment and the level of aggressive strategy of the youth's coping with a social conflict situation (considering the group as a whole and distinguished by sex).

In general, based on the data presented in Table 2, a strong correlation may be noticed between the self-assessment level and the youth's aggressive strategy of coping with a social conflict situation. It is expressed in a tendency to an increased level of aggressive strategy applied by youth in a social conflict situation together with a decreased level of their self-assessment and opposite - in a tendency to a decreased level of aggressive strategy applied by youth in a social conflict situation together with an increased level of self-assessment.

In order to verify possible correlations between the level of fear, anger and curiosity understood as a current emotional state and as a personality trait, and an aggressive strategy of handling a social conflict situation, results in the TISCO inventory and in the Aggression (A) scale of the KSMK questionnaire have been correlated. Table 3 presents Pearson's $r$ correlation coefficients for the whole group and for groups distinguished by their sex.

Table 3 shows that the correlation between anger as an emotional state felt at a given moment and the scale of aggressive strategy is statistically significant for the whole group $(r=0.25)$, for girls $(r=0.21)$ and boys $(r=0.27)$ separately $(p<0.001)$. A low correlation may be noticed: the higher the level of anger understood as a temporary state experienced in relation to a social conflict situation in which gymnasium school students are, the more often they apply an aggressive strategy in action. It may be assumed that the value of aggressive coping with a social conflict situation will increase as the value of situational anger increases. Moreover, a significantly weak positive correlation between anger as a personality trait and the scale of aggressive strategy of coping has been obtained for the whole group $(r=0.35)$, for girls $(r=0.37)$ and boys $(r=0.33)$. Therefore, it seems that in the case of adolescents, the level of anger as a trait determines an intensified aggressive strategy. The interpretation of the obtained correlation is the following: the higher the level of trained disposition

Table 3

Summary of values of Pearson's r correlation coefficients in the TISCO Inventory scales and in the Aggression (A) scale of the KSMK questionnaire for the whole group $(n=811)$, for girls $(n=414)$ and boys $(n=397)$

\begin{tabular}{cccc}
\hline $\begin{array}{c}\text { Scales of the TISCO } \\
\text { questionnaire }\end{array}$ & \multicolumn{3}{c}{ "A" scale of the KSMK questionnaire } \\
\cline { 2 - 3 } & Girls & Boys & Total \\
\hline Anger - state & 0.21 & 0.27 & 0.25 \\
& $p<0.001$ & $p<0.001$ & $p<0.001$ \\
Anger - trait & 0.37 & 0.33 & 0.35 \\
& $p<0.001$ & $p<0.001$ & $p<0.001$ \\
Fear - state & -0.04 & 0.16 & 0.06 \\
& $p<0.46$ & $p<0.001$ & $p<0.09$ \\
Fear - trait & 0.16 & 0.21 & 0.17 \\
& $p<0.001$ & $p<0.001$ & $p<0.001$ \\
Curiosity - state & -0.05 & -0.10 & -0.08 \\
& $p<0.28$ & $p<0.04$ & $p<0.03$ \\
Curiosity - trait & 0.02 & -0.06 & -0.02 \\
& $p<0.77$ & $p<0.28$ & $p<0.62$ \\
\hline
\end{tabular}


to react with anger, the more often adolescents use an aggressive strategy in a social conflict situation.

Table 3 shows a weak correlation between fear as a current emotional state and the strategy of aggression in the group of boys $(r=0.16)$. At the same time, the results of the statistical analyses make it possible to assume that the mentioned relations are somehow determined by the respondents' sex, because they are significant for boys, but not for girls. The correlations may be interpreted as follows: the higher the level of fear understood as an emotional state felt at a given moment, the higher the level of aggressive strategy of boys coping with a social conflict situation. Moreover, a statistically significant $(p<0.001)$ weak correlation coefficient has been obtained between the level of fear understood as a personality trait and the strategy of aggression for the whole group $(r=0.17)$, which is confirmed also in the group of girls $(r=0.16)$ and boys $(r=0.21)$. The interpretation of the obtained correlation is the following: the higher the level of fear, the more often adolescents use an aggressive strategy in a social conflict situation. A trained disposition to perceive objectively harmless social situations as threatening and to react with fear that is disproportionate to the size of the threat is related to a trained disposition to aggressive coping with a social conflict.

Table 3 shows that the correlation between the curiosity as a current emotional state and the scale of aggressive strategy is statically insignificant for the group of girls $(p<0.05)$. In turn, a statistically significant weak negative correlation between the level of curiosity and the scale of aggressive coping has been obtained for the whole group $(r=-0.08)$ and for boys $(r=-0.10)$. Moreover, the results indicate no significant correlation between the curiosity understood as a relatively permanent personality trait and the strategy of aggression for the whole group of respondents and for both groups split with respect to their sex. It makes it possible to assume that a trained disposition to perceive a difficult situation as a challenge and to react with curiosity is not related to a trained disposition to aggressive coping with a social conflict.

To our knowledge, $r$-Pearson correlation coefficients are at a weak and low level, however they are statistically significant $(p<0.001)$ and support the statement that teenagers applying an aggressive strategy while coping with a social conflict appear to be susceptible to experiencing anger and fear of a diverse origin (state, trait). It means that in situations of a social conflict they are prone to react with negative emotions (anger, fear).

The analysis of stepwise multiple regression has been conducted to study more thoroughly the way the set of emotional variables co-determines the level of aggressive strategy of coping with a social conflict situation by youth. Results in the Aggression scale of the KSMK questionnaire have been adopted as a de- pendent variable, while the set of independent variables includes the results in six scales: Anger - state and Anger - trait, Fear - state and Fear - trait and Curiosity - state and Curiosity - trait of the TISCO Inventory. Results are presented in Table 4.

The first analysis has been based on the results of the whole respondent group, regardless of their sex. As Table 4 shows, four independent variables affect significantly the aggressive strategy of coping with a social conflict by youth: anger - state, fear - state, curiosity - state, and fear - trait. These variables explain $15 \%$ variance of a dependent variable. $\beta$ values indicate that the higher the level of fear understood as a temporary state experienced in relation to conflict and the higher the level of fear as a personality trait and the lower the level of situational fear and the lower the level of curiosity understood as an emotional state felt at a given moment, the more often youth apply an aggressive strategy when coping with a social conflict situation.

Separate analyses have been conducted for groups distinguished by sex (Table 4). Stepwise regression analysis has indicated that three of all independent variables introduced to the regression model are significant in explanation of the aggressive strategy of coping with a social conflict by girls: anger - state, fear - state and anger - trait. These three variables collectively explain $17 \%$ variability of results in the Aggression scale of the KSMK questionnaire. $\beta$ values indicate that the higher the level of fear understood as an emotional state experienced at a given moment and the higher the level of anger as a relatively permanent trait and the lower the level of situational fear, the more often girls apply an aggressive strategy when coping with a social conflict situation.

In addition, it has been verified which set of independent variables affects the level of aggressive strategy in a social conflict situation among boys (see Table 4). Three independent variables appear to be significant in a regression equation. They include anger - state, curiosity - state and anger - trait. $\beta$ values indicate that the higher the level of situational anger and the higher the level of the trained disposition to react with anger and the lower the level of curiosity understood as an emotional state felt at a given moment, the more often boys apply an aggressive strategy when coping with a social conflict situation. Multiple determination coefficient $R^{2}=0.14$ indicates that $14 \%$ variance of the dependent variable "aggressive strategy" in the group of boys explains independent variables foreseen in a theoretical model. Other independent variables considered in the research appear to be insignificant determinants of the aggressive strategy.

To sum up, the analysis of multiple regression indicates that mainly anger as an emotional state felt at a given moment and a trained disposition to react with anger affect the aggressive strategy of coping 
The role of self-assessment and emotions in designation of an aggressive strategy of coping with a social conflict situation by gymnasium school students

Table 4

Stepwise multiple regression of the Aggression scale results of the KSMK questionnaire against the TISCO Inventory scales: for the whole group $(n=811)$, for girls $(n=414)$ and boys $(n=397)$

\begin{tabular}{ccccccc}
\hline Respondents & Variable & $\beta$ & $B$ & $\begin{array}{c}\text { Statistical } \\
\text { error } B\end{array}$ & $t$ & Level $p<$ \\
\hline \multirow{6}{*}{ Total } & Anger - state & 0.17 & 0.14 & 0.04 & 3.81 & 0.0002 \\
& Fear - state & -0.09 & -0.16 & 0.07 & -2.31 & 0.02 \\
& Curiosity - state & -0.08 & -0.10 & 0.04 & -2.55 & 0.01 \\
& Anger - trait & 0.30 & 0.27 & 0.03 & 8.14 & 0.000001 \\
& W. Free & & 4.34 & 1.67 & 2.59 & 0.01
\end{tabular}

Multiple correlation coefficient: $R=0.38$

Multiple determination coefficient: $R^{2}=0.15$

Equation significance: $F(4.806)=34.78 ; p<0.00001$

Standard error of estimation: 5.10

\begin{tabular}{|c|c|c|c|c|c|c|}
\hline \multirow{4}{*}{ Girls } & Anger - state & 0.20 & 0.17 & 0.05 & 3.32 & 0.001 \\
\hline & Fear - state & -0.21 & -0.36 & 0.09 & -3.85 & 0.0001 \\
\hline & Anger - trait & 0.33 & 0.31 & 0.05 & 6.65 & 0.000001 \\
\hline & W. Free & & 4.33 & 1.86 & 2.33 & 0.02 \\
\hline
\end{tabular}

Multiple correlation coefficient: $R=0.42$

Multiple determination coefficient: $R^{2}=0.17$

Equation significance: $F(3.410)=28.64 ; p<0.00001$

Standard error of estimation: 5.12

$\begin{array}{ccrrrrl} & \text { Anger - state } & 0.14 & 0.12 & 0.04 & 2.71 & 0.007 \\ \text { Boys } & \text { Curiosity - state } & -0.12 & -0.14 & 0.06 & -2.47 & 0.01 \\ & \text { Anger - trait } & 0.26 & 0.23 & 0.05 & 4.84 & 0.000002 \\ & \text { W. Free } & & 3.47 & 1.76 & 1.96 & 0.05\end{array}$

Multiple correlation coefficient: $R=0.37$

Multiple determination coefficient: $R^{2}=0.14$

Equation significance: $F(3.393)=20.88 ; p<0.00001$

Standard error of estimation: 5.02

with a social conflict situation. It may be supposed that together with the increased level of anger as a state and a trait, an aggressive strategy of youth's coping with a social conflict situation (considering the group as a whole and with respect to sex) may be intensified. Moreover, there have been noticed significant negative relations among the aggressive strategy and fear as a current emotional state and the curiosity as an emotional state felt at a given moment. It may be expected that the higher the intensity of youth's aggressive strategy of coping with a social conflict situation, the lower the level of situational fear and the lower the level of curiosity as a current emotional state. It should also be emphasised that emotional variables constitute quite weak predicators of aggressive strategy of youth's coping with a social conflict situation, which is proven by a low multiple determination coefficient $R^{2}=0.14-0.17$.

\section{DISCUSSION}

The results of the conducted analyses indicate a connection of self-assessment and negative emotions with an aggressive strategy of coping with a social conflict situation by youth. In the course of this analysis, it has been stated that an aggressive approach to other persons (e.g. mutual dislike, unkindness, blaming) in a situation that causes a hazard to fulfilment of a young person's endeavour constitutes a form of behaviour usually concurrent with a low level of general self-assessment. Adolescents (considering the respondents as a whole and with respect to sex) using an aggressive strategy of coping with a social conflict assess themselves low. A person with low self-assessment in a state of personal threat resulting from conflicting relations with others directs its operation to the defence of the sense of self-con- 
fidence, instead of concentrating on a problem. As a consequence, aggression against the environment arises. Then, aggression becomes an attempt to cope with the threat of one's own "self" security. An adolescent tries to mask a threat to their image through accusations or diminishing others' value, which is related to conflict provocation. It should be stated that a low level of self-assessment plays a role in the preference of choosing an aggressive strategy of coping with a social conflict situation (see Kubacka-Jasiecka, 1995; Borecka-Biernat, 2006).

In addition, the analysis of the research results has shown that youth (considering the respondents as a whole and with respect to sex) applying an aggressive strategy in social conflicts show a higher level of anger as an emotional state experienced due to this situation and a higher level of a trained disposition to react with anger. Therefore, anger leads to aggressive actions aimed at removal of the threat or recovery of lost objectives. It means that the higher the intensity of the youth's aggressive strategy of coping with a social conflict situation, the higher the level of anger of a diverse origin (state, trait) (see Berkowitz, 1992; Ranschurg, 1993; Pufal-Struzik, 1997; Doliński, 2000; Kossewska, 2008).

The research conducted has demonstrated also that adolescents (considering the respondents as a whole and with respect to sex) using an aggressive strategy of coping with a social conflict are susceptible to experience fear as a trait. A trained disposition to perceive objectively harmless social situations as threatening and to react with fear that is disproportionate to the size of the threat is directly related to a trained disposition to aggressive coping with a social conflict. A felt threat favours generation of a dislike and aggressive approach towards others. It means that increased fear as a trait in adolescents in interpersonal situations, which poses a threat to fulfilment of their endeavour, is accompanied by an increased level of an aggressive strategy (see Kubacka-Jasiecka, 1986; Ranschburg, 1993).

It should also be noted that youth applying an aggressive strategy in a social conflict situation are characterised by a lower level of curiosity as a state (both for the whole group and for boys). Here the views of Fredrickson (2001) should be mentioned. He claims that positive emotions - joy, satisfaction, interest, pride, love - extend cognitively the field of vision and lead to use the strategies connected with searching for solutions in difficult situations. It is noticeable that difficult situations generate positive emotions which are not favouring aggressive coping with setbacks.

To generalise the above results, it may be stated that a low level of self-assessment plays some role in choosing an aggressive strategy of coping with a social conflict situation by youth. Adolescents are aware of their skills and limitations affecting their way of functioning in a social conflict situation, which experienced by teenagers may contribute to the intensified feeling of negative emotions and discomfort caused by difficulties with solving problems. Youth by applying aggressive strategies in a social conflict situation demonstrate a significantly higher level of the state of anger experienced in relation to this situation and a higher level of a trained disposition to react with anger and fear. This makes it possible to assume that when negative emotions (fear, anger) reach a significant level of intensity, they reduce cognitive curiosity, hamper spontaneous activity, decrease motivation to undertake transgressive actions, launch behaviours of the aggression type in a hazardous situation, and these are used to reduce negative emotional stimulation, at least for some time.

\section{REFERENCES}

Berkowitz, L. (1992). O powstawaniu i regulowaniu gniewu i agresji [On Formation and Regulation of Anger and Aggression]. Psychological News, 1-2, 87105.

Bishop, G. (2000). Psychologia zdrowia [Health Psychology]. Wrocław: Wydawnictwo Astrum.

Borecka-Biernat, D. (2006). Strategie radzenia sobie młodzieży w trudnych sytuacjach społecznych. Psychospoteczne uwarunkowania [The Youth's Strategies of Coping with Difficult Social Situations. Psychosocial Determinants]. Wrocław: Wydawnictwo Uniwersytetu Wrocławskiego.

Borecka-Biernat, D. (2012). Kwestionariusz strategii radzenia sobie młodzieży w sytuacji konfliktu społecznego [The Questionnaire of the Youth's Strategies of Coping with the Social Conflict Situation]. Pedagogical Psychology, 1-2, 86-118.

Clark, L. \& Watson, D. (2002). Funkcjonalne i dysfunkcjonalne reakcje uczuciowe [Functional and Dysfunctional Emotional Reactions]. In: P. Ekman \& R. Dawidson (eds.). Natura emocji - podstawowe zagadnienia [The Nature of Emotions. Fundamental Questions] (pp. 119-125). Gdańsk: Gdańskie Wydawnictwo Psychologiczne.

Doliński, D. (2000). Emocje, poznanie i zachowanie [Emotions, Cognition and Behaviour]. In: J. Strelau (ed.). Psychologia. Podręcznik akademicki [Psychology. Academic Textbook] (pp. 369-394). Gdańsk: Gdańskie Wydawnictwo Psychologiczne.

Donaldson, Ph. (2000). Patterns of Children's Coping with Life Stress. American Journal of Orthopsychiatry, 70, 351-359.

Eftimie, S. \& lonescu, S. (2010). Self-Esteem on Aggressive Adolescents. Buletinul UniversităŃii Petrol - Gaze din Ploiesti, Seria StiinŃele EducaŃiei, 62, 146-153.

Frączek, A. (2003). Wszystko o twojej agresji [All About Your Aggression]. Charaktery, 7, 28-30. 
The role of self-assessment and emotions in designation of an aggressive strategy of coping with a social conflict situation by gymnasium school students

Fredrickson, B. (2001). The Role of Positive Emotions in Positive Psychology. American Psychologist, 56, 218-226.

Guliford, J. (1970). Podstawowe metody statystyczne w psychologii i pedagogice [Basic Statistical Methods in Psychology and Pedagogics]. Warszawa: PWN.

Guszkowska, M., Gorący, A. \& Rychta-Siedlecka, J. (2001). Ważne zdarzenia życiowe i codzienne kłopoty jako źródło stresu w percepcji młodzieży [Important Life Events and Everyday Troubles as the Source of Stress in Perception of the Youth]. Edukacja Otwarta, 4, 155-164.

Jaworski, R. (2000). Konflikt pokoleń w okresie adolescencji. Psychologiczne aspekty radzenia sobie ze stresem [Generation Gap in the Adolescence. Psychological Aspects of Coping with Stress]. In: R. Jaworski, A. Wielgus \& J. Łukjaniuk (eds.). Problemy człowieka w świecie psychologii [Human Problems in the World of Psychology] (pp. 27-54). Płock: Wydawnictwo Naukowe NOVUM.

Jelonkiewicz, I. \& Kosińska-Dec, K. (2008). Jasna strona stresu młodzieży (emocje pozytywne w radzeniu sobie) [Bright Side of the Youth's Stress (Positive Emotions in Coping]. In: I. Heszen \& J. Życińska (eds.). Psychologia zdrowia w poszukiwaniu pozytywnych inspiracji [Psychology of Health. In the Search for Positive Inspirations] (pp. 55-66). Warszawa: Wydawnictwo SWPS “Academica”.

Kępiński, A. (1992). Lęk [Fear]. Kraków: Wydawnictwo Sagittarius.

Kobus, K. \& Reyes, O. (2000). A Descriptive Study of Urban Mexican American Adolescents' Perceived Stress and Coping. Hispanic Journal of Behavioural Sciences, 22, 163-178.

Kosińska-Dec, K. \& Jelonkiewicz, I. (1995). Sposoby radzenia sobie przez rodziców z zaburzeniami emocjonalnymi i chorobą somatyczną dziecka [The Ways Parents Cope with Emotional Disorders and a Somatic Disease of Their Child]. Pedagogical Psychology, 4, 337-349.

Kossewska, J. (2008). Zasoby osobowe a agresja interpersonalna u młodzieży gimnazjalnej [Personal Resources and Interpersonal Aggression at the Youth of the Grammar School]. In: H. Wrona-Polańska (ed.). Zdrowie-stres-choroba $w$ wymiarze psychologicznym [Health-Stress-Disease in the Psychological Dimension] (pp. 145-159). Kraków: Wydawnictwo Impuls.

Kozielecki, J. (1981). Psychologiczna teoria samowiedzy [The Psychological Theory of Self-Knowledge]. Warszawa: PWN.

Krzyśko, M. (1999). Styl atrybucyjny a sposoby radzenia sobie młodzieży w trudnych sytuacjach szkolnych i pozaszkolnych [The Attributive Style and the Ways the Youth Cope with Difficult School and Non-School Situations]. In: W. Kojsa, R. Mrózka \& R. Studenski (eds.). Młodzież w sytuacjach zmian gospodarczych, edukacyjnych, spotecznych i kultu- rowych [The Youth in Situations of Economic, Educational, Social and Cultural Changes] (Vol. 1, pp. 265276). Cieszyn: Wydawnictwo UŚ Filia w Cieszynie.

Kubacka-Jasiecka, D. (1986). Struktura ja a zwiqzek między agresywnościq i lękliwościa [The Structure of Self and the Relation between Aggressiveness and Timidity]. Kraków: Wydawnictwo Uniwersytetu Jagiellońskiego.

Kubacka-Jasiecka, D. (1995). Młodzieżowe zachowania agresywne w zmaganiu się z zagrożeniem Ja [Teenagers' Aggressive Behaviours in Struggle with a Threat to the Self]. Quarterly of the Polish Developmental Psychology, 3, 3-21.

Kulas, H. (1986). Samoocena mtodzieży [Self-Assessment of the Youth]. Warszawa: Wydawnictwa Szkolne i Pedagogiczne.

Lazarus, R. (2001). The Paradigm of Stress and Coping. Psychological News, 3-4, 2-40.

Leary, M. \& Kowalski, R. (2001). Lęk spoteczny [The Social Fear]. Gdańsk: Gdańskie Wydawnictwo Psychologiczne.

Łaguna, M., Lachowicz-Tabaczek, K. \& Dzwonkowska, I. (2007). Skala samooceny SES Morrisa Rosenberga - polska adaptacja metody [The SES Self-Esteem Scale by Morris Rosenberg - Polish Adaptation of the Method]. Social Psychology, 2, 164-176.

Łosiak, W. (1995). Umiejscowienie kontroli, percepcja sytuacji a lęk w sytuacji egzaminacyjnej [Locus of Control, Perception of Situation and Fear in the Situation of an Exam]. Annual of the Pedagogical Studies Committee, 47, 107-114.

Łosiak, W. (2009). Stres i emocje w naszym życiu [Stress and Emotions in Our Life]. Warszawa: Wydawnictwa Akademickie i Profesjonalne.

Matusewicz, Cz. (1997). Konflikty w zespołach uczniowskich [Conflicts in Students' Groups]. In: W. Pomykało (ed.). Encyklopedia pedagogiczna [Pedagogical Encyclopaedia] (pp. 285-287). Warszawa: Fundacja Innowacja.

Miłkowska, G. (2012). Agresja w okresie dorastania - charakterystyka, przejawy, przeciwdziałanie [Aggression in the Period of Adolescence - Characteristics, Symptoms, Prevention]. In: Z. Izdebski (ed.). Zagrożenia okresu dorastania [Dangers of the Adolescence] (pp. 91-110). Zielona Góra: Oficyna Wydawnicza Uniwersytetu Zielonogórskiego.

Miłkowska-Olejniczak, G. (2002). Szkolne uwarunkowania zachowań agresywnych dzieci i młodzieży [School Determinants of Aggressive Behaviours at Children and Youth]. In: A. Doliński (ed.). Modelowe rozwiqzania dziatalności profilaktycznej w grupach dzieci i mtodzieży [Model Solutions of the Preventive Measures in Children and Youth Groups] (pp. 57-70). Zielona Góra: Komenda Chorągwi Ziemi Lubuskiej ZHP.

Nitendel-Bujakowa, E. (2001). Lęki szkolne jako wyznacznik funkcjonowania dziecka [School Fears as 
a Determinant of Child's Functioning]. Issues of the Psychological and Pedagogical Guidance, 1, 15-37.

Ogińska-Bulik, N. (2001). Zasoby osobiste jako wyznaczniki radzenia sobie ze stresem [Personal Resources as Determinants of Coping with Stress]. Acta Universitatis Lodziensis folia Psychologica, 5, 83-93.

Plewicka, Z. (1977). Sytuacje konfliktowe uczniów w szkole [Conflict Situations of Students at School]. In: M. Tyszkowa (ed.). Zachowanie się młodzieży w sytuacjach trudnych a rozwój osobowości [The Youth's Behaviour in Difficult Situations and Development of Personality] (pp. 37-50). Poznań: Wydawnictwo Naukowe UAM.

Polak, K.(2010). Uczeń w sytuacji konfliktów szkolnych [A Student in the Situation of School Conflicts]. In: D. Borecka-Biernat (ed.). Sytuacje konfliktu w środowisku rodzinnym, szkolnym i rówieśniczym: jak sobie radza z nimi dzieci i mtodzież? [Conflict Situations in Family, School and Peer Environment] (pp. 23-40). Warszawa: Dyfin.

Pufal-Struzik, I. (1997). Niektóre cechy osobowości młodzieży agresywnej [Some Personality Traits of Aggressive Teenagers]. Pedagogical Psychology, 2, 151-156.

Ranschburg, J. (1993). Lęk, gniew, agresja [Fear, Anger, Aggression]. Warszawa: Wydawnictwa Szkolne i Pedagogiczne.

Reykowski, J. (1970). „Obraz własnej osoby” jako mechanizm regulujący postępowanie ["Image of Self" as a Behaviour-Regulating Mechanism]. Pedagogical Quarterly, 3, 45-57.

Rostowska, T. (2001). Konflikt międzypokoleniowy w rodzinie. Analiza psychologiczna [Generation Gap in Family. Psychological Analysis]. Łódź: Wydawnictwo Uniwersytetu Łódzkiego.

Różańska-Kowal, J. (2004). Szkoła jako główne źródło stresu młodzieży w wieku dorastania [School as the Main Source of Stress for the Adolescents]. Pedagogical Quarterly, 3, 203-214.

Sikora, R. \& Pisula, E. (2008). Wiek i płeć a radzenie sobie ze stresem przez młodzież w wieku 12-17 lat [Age and Sex and Coping with Stress by the Youth Aged 12-17]. Psychological Review, 51, 405-421.

Skorny, Z. (1987). Dziecko agresywne - objawy, przyczyny, przeciwdziałanie [An Agressive Child - Symptoms, Reasons, Prevention]. In: W. Pomykało (ed.). Vademecum dla rodziców dzieci od lat 6 do 10 [Vademecum for Parents of Children Aged 6-10] (pp. 97-102). Warszawa: Wydawnictwo Współczesne.

Stach, R. (1989). Zachowanie agresywne [Aggressive Behaviour]. Wrocław: Ossolineum.

Terelak, J. (2001). Psychologia stresu [The Psychology of Stress]. Bydgoszcz: Oficyna Wydawnicza „Branta”.

Tyszkowa, M. (1977). Zachowanie się dzieci i młodzieży w sytuacjach trudnych. [Behaviour of Children and Youth in Difficult Situations]. In: M. Tyszkowa (ed.). Zachowanie się mtodzieży w sytuacjach trud- nych a rozwój osobowości [The Youth's Behaviour in Difficult Situations and Development of Personality] (pp. 7-17). Poznań: Wydawnictwo Naukowe UAM.

Tyszkowa, M. (1979). Funkcjonowanie dzieci w sytuacjach trudnych [The Children's Functioning in Difficult Situations]. Oświata i Wychowanie, 6, 210217.

Tyszkowa, M. (1986). Zachowanie się dzieci w sytuacjach trudnych [The Children's Behaviour in Difficult Situations]. Warszawa: PWN.

Tyszkowa, M. (1997). Odporność psychiczna [Psychic Immunity]. In: W. Pomykało (ed.). Encyklopedia pedagogiczna [Pedagogical Encyclopaedia] (pp. 475478). Warszawa: Wydawnictwo Fundacja Innowacja. Witkin, G. (2000). Stres dziecięcy [The Child Stress]. Poznań: Dom Wydawniczy REBIS.

Woźniak-Krakowian, A. \& Wieczorek, G. (2009). Przemoc w szkole jako zjawisko społeczne [Violence at School as a Social Phenomenon]. In: A. Woźniak-Krakowian, E. Napora \& I. Gomółka-Walaszek (eds.). Problemy marginalizacji dzieci i mtodzieży [The Issues of Children and Youth Marginalisation] (pp. 115-150). Częstochowa: Wydawnictwo AJD.

Wrześniewski, K. (1991). Trójczynnikowy inwentarz stanów i cech osobowości [Three-Factor Personality States and Traits Inventory]. Medical Review, 48, 222-225.

Wrześniewski, K. (1996). Style a strategie radzenia sobie ze stresem. Problemy pomiaru [Styles and Strategies of Coping with Stress. Measurement Issues]. In: I. Heszen-Niejodek \& Z. Ratajczak (ed.). Człowiek w sytuacji stresu. Problemy teoretyczne i metodologiczne [Human Being in the Situation of Stress. Theoretical and Methodological Issues] (pp. 44-64). Katowice: Wydawnictwo UŚ. 